\title{
The Influence of Extracellular Hydrogen on the Metabolism of Bacteroides ruminicola, Anaerovibrio lipolytica and Selenomonas ruminantium
}

\author{
By C. HENDERSON† \\ Microbiology Department, Rowett Research Institute, Bucksburn, \\ Aberdeen $A B 2$ 9SB, Scotland
}

(Received 3 September 1979; revised 25 February 1980)

\begin{abstract}
Strains of three anaerobic rumen bacteria, Bacteroides ruminicola, Anaerovibrio lipolytica and Selenomonas ruminantium, were able to use extracellular $\mathrm{H}_{2}$ to reduce fumarate to succinate. Each bacterium possessed membrane-bound hydrogenase and fumarate reductase activity. Membrane-bound cytochrome $b$ was reducible by $\mathrm{H}_{2}$ and oxidizable by fumarate in each bacterium. The apparent $K_{m}$ values for hydrogen of the hydrogenases were $4.5 \times 10^{-6} \mathrm{M}$, $1.4 \times 10^{-5} \mathrm{M}$ and $4.4 \times 10^{-5} \mathrm{M}$ for $B$. ruminicola, $A$. lipolytica and $S$. ruminantium, respectively. The apparent $K_{\mathrm{m}}$ values for fumarate of the fumarate reductases were approximately $1.0 \times 10^{-4} \mathrm{M}$ for each bacterium.
\end{abstract}

\section{INTRODUCTION}

When inhibitors of rumen methanogenic bacteria are fed to ruminants the resulting depression of methane production is accompanied by an accumulation of $\mathrm{H}_{2}$ and an increase in the proportion of propionic acid relative to acetic acid in the rumen (Demeyer \& Van Nevel, 1975). It may be that the accumulating $\mathrm{H}_{2}$ so decreases growth of those rumen bacteria which form acetate as their main product (Hungate, 1966) as to allow the propionate-producing bacteria to compete more successfully for fermentable substrate. Alternatively, the $\mathrm{H}_{2}$ produced by the acetate-producing bacteria might be used directly by the propionate producers to increase the proportion of pyruvate which is reduced to propionate and thus increase the ratio of propionate to acetate produced.

In the present study several important propionate- and succinate-producing rumen bacteria were tested for their ability to utilize extracellular $\mathrm{H}_{2}$ as a source of reducing power. Such activity has been shown to be the main source of energy for the nonfermentative rumen bacterium Vibrio succinogenes which requires an exogenous supply of $\mathrm{H}_{2}$ (or formate) and fumarate (Wolin et al., 1961). The reduction of fumarate to succinate by $V$. succinogenes is accompanied by electron transport-linked phosphorylation (Reddy $\&$ Peck, 1978).

\section{METHODS}

Anaerovibrio lipolytica 5S was the strain of Hobson (1965); it was grown on the medium described by Henderson (1971) with fructose as energy source. Selenomonas ruminantium strains 17 and WPL151/1 were isolated at the Rowett Research Institute as described by Hobson \& Mann (1961); they were grown on medium H5 which was based on medium 1 of Kurihara et al. (1968) with rumen fluid replaced by distilled

† Present address: Robert Gordon's Institute of Technology, School of Nutritional Science, Kepplestone Premises, Queens Road, Aberdeen AB9 2PG. 
water and with $0.6 \%(\mathrm{w} / \mathrm{v})$ glucose as the sole energy source. Bacteroides ruminicola $46 / 52$ was the strain of Lysons et al. (1971) and B. ruminicola strains M3/12, M3/17 and 41/21 were isolated by Mr S. O. Mann at the Rowett Research Institute; these bacteria were grown on medium H5. Megasphaera elsdenii type 2 was the Large Coccus type 2 described by Hobson et al. (1958); it was grown on medium H5 or H5 with glucose replaced by $0.7 \%(w / v)$ sodium lactate.

Bacteria were grown anaerobically in batch cultures in vessels designed, as described by Jarvis et al. (1978), for direct turbidimetric measurements. The cultures were shaken in a New Brunswick G24 Environmental Incubator Shaker at $200 \mathrm{rev}$. $\mathrm{min}^{-1}$ at $38^{\circ} \mathrm{C}$. Growth, under atmospheres of either $\mathrm{O}_{2}$-free $\mathrm{CO}_{2}$ or $\mathrm{O}_{2}$-free $\mathrm{H}_{2} / \mathrm{CO}_{2}(80: 20, \mathrm{v} / \mathrm{v})$ was monitored until the end of exponential growth when samples were removed for measurement of bacterial dry weight, lactate and succinate concentrations and utilization of substrate (Henderson, 1975). Volatile fatty acids were assayed by gas-liquid chromatography (Fell et al., 1968), concentrations being deduced from peak areas by comparison with standard curves.

Washed cell suspensions of bacteria were prepared under $\mathrm{O}_{2}$-free $\mathrm{N}_{2}$ atmospheres by centrifugation of large batch cultures $(400 \mathrm{ml})$ and washing with $0.1 \mathrm{M}$-phosphate buffer $\mathrm{pH} 7.2$ made anaerobic by flushing with $\mathrm{O}_{2}$-free $\mathrm{N}_{2}$. Broken cell suspensions were prepared anaerobically at $5{ }^{\circ} \mathrm{C}$ from washed bacteria by ultrasonic disruption using the Dawe Soniprobe (Dawe Instruments, London) set at maximum output $(8 \times 30 \mathrm{~s}$ bursts with $30 \mathrm{~s}$ cooling pauses). Unbroken bacteria were removed by centrifugation at $5000 \mathrm{~g}$ for $20 \mathrm{~min}$. Membrane preparations were made from the broken cell suspensions by centrifugation at $100000 \mathrm{~g}$ for $120 \mathrm{~min}$. The membrane pellet was resuspended in the original volume of $0 \cdot 1 \mathrm{M}$-phosphate buffer $\mathrm{pH} 7 \cdot 2$. All preparations were stored under $\mathrm{O}_{2}$-free $\mathrm{N}_{2}$ at $-60^{\circ} \mathrm{C}$.

Hydrogenase activity was assayed spectrophotometrically by measuring the increase in absorbance at $546 \mathrm{~nm}$ caused by the reduction of benzyl viologen $\left(\epsilon=97501 \mathrm{~mol}^{-1} \mathrm{~cm}^{-1}\right)$. The reaction mixture, in a cuvette of $1 \mathrm{~cm}$ optical pathlength, consisted of $0.1 \mathrm{M}$-phosphate buffer $\mathrm{pH} 7.2,1.66 \mathrm{~mm}$-benzyl viologen and $0.05 \mathrm{ml}$ enzyme preparation. The phosphate buffer used was made anaerobic by sparging with $\mathrm{O}_{2}$-free $\mathrm{N}_{2}$. Hydrogen was added as a saturated solution in $0.1 \mathrm{M}$-phosphate buffer $\mathrm{pH} 7.2 ; 2.0 \mathrm{ml}$ of this solution were injected through a rubber stopper into the reaction mixture in the cuvette. Formate dehydrogenase was assayed by a similar method, with $1 \mathrm{~mm}$-sodium formate in $0.1 \mathrm{M}$-phosphate buffer $\mathrm{pH} 7.2$ replacing the $\mathrm{H}_{2}$ solution. The final volumes in these assays were $3.0 \mathrm{ml}$. These methods were adapted from the formate dehydrogenase assay of Kröger \& Innerhofer (1976). The fumarate reductase assay was adapted from that of Kröger \& Innerhofer (1976). The reaction mixture (final volume $3.0 \mathrm{ml}$ ) consisted of $0 \cdot 1 \mathrm{M}$-phosphate buffer $\mathrm{pH} 7 \cdot 2,0.166 \mathrm{~mm}$-benzyl viologen, $0.166 \mathrm{~mm}$-sodium dithionite and $0.05 \mathrm{ml}$ enzyme preparation and the reaction was started by adding $6.66 \mathrm{~mm}$-fumarate. Strict precautions were taken to ensure absence of $\mathrm{O}_{2}$ and the gas phase was $\mathrm{O}_{2}$-free $\mathrm{N}_{2}$.

Cytochrome $b$ was determined from reduced minus oxidized difference spectra (De Vries $e t$ al., 1974), using the Cary 15 spectrophotometer (Cary Instruments, Calif., U.S.A.).

\section{RESULTS AND DISCUSSION}

Table 1 shows the effect of $\mathrm{H}_{2} / \mathrm{CO}_{2}(80: 20$, v/v) gas phase on the fermentation products of the bacteria grown in shaken batch cultures. In each strain of $B$. ruminicola, adding $\mathrm{H}_{2}$ increased the proportion of succinate formed by fermentation of glucose and decreased the proportion of lactate. A small drop in the proportion of acetate formed was usually observed, but this was less consistent than the other changes. No significant changes in molar growth yield ( $\left.Y_{\text {eubstrate }}\right)$ were observed.

With $A$. lipolytica, adding $\mathrm{H}_{2}$ increased the proportions of propionate and succinate relative to acetate when fructose was fermented. The increase in molar growth yield in the presence of $\mathrm{H}_{2}$ may have been due mainly to an observed increase in the growth rate of the bacteria in these cultures which would mean relatively less energy was expended on maintenance (Pirt, 1965).

The two strains of $S$. ruminantium had different fermentation patterns under $\mathrm{CO}_{2}$ and reacted differently to the addition of $\mathrm{H}_{2}$. Selenomonas ruminantium strain 17 produced no lactate, and under $\mathrm{H}_{2} / \mathrm{CO}_{2}$ atmospheres propionate production was stimulated at the expense of acetate production with only slight increases in succinate. Selenomonas ruminantium strain WPL151/1 produced lactate as a major product, and under $\mathrm{H}_{2} / \mathrm{CO}_{2}$ atmospheres propionate and succinate production increased at the expense of lactate. No significant effects on molar growth yields were recorded. The lack of 


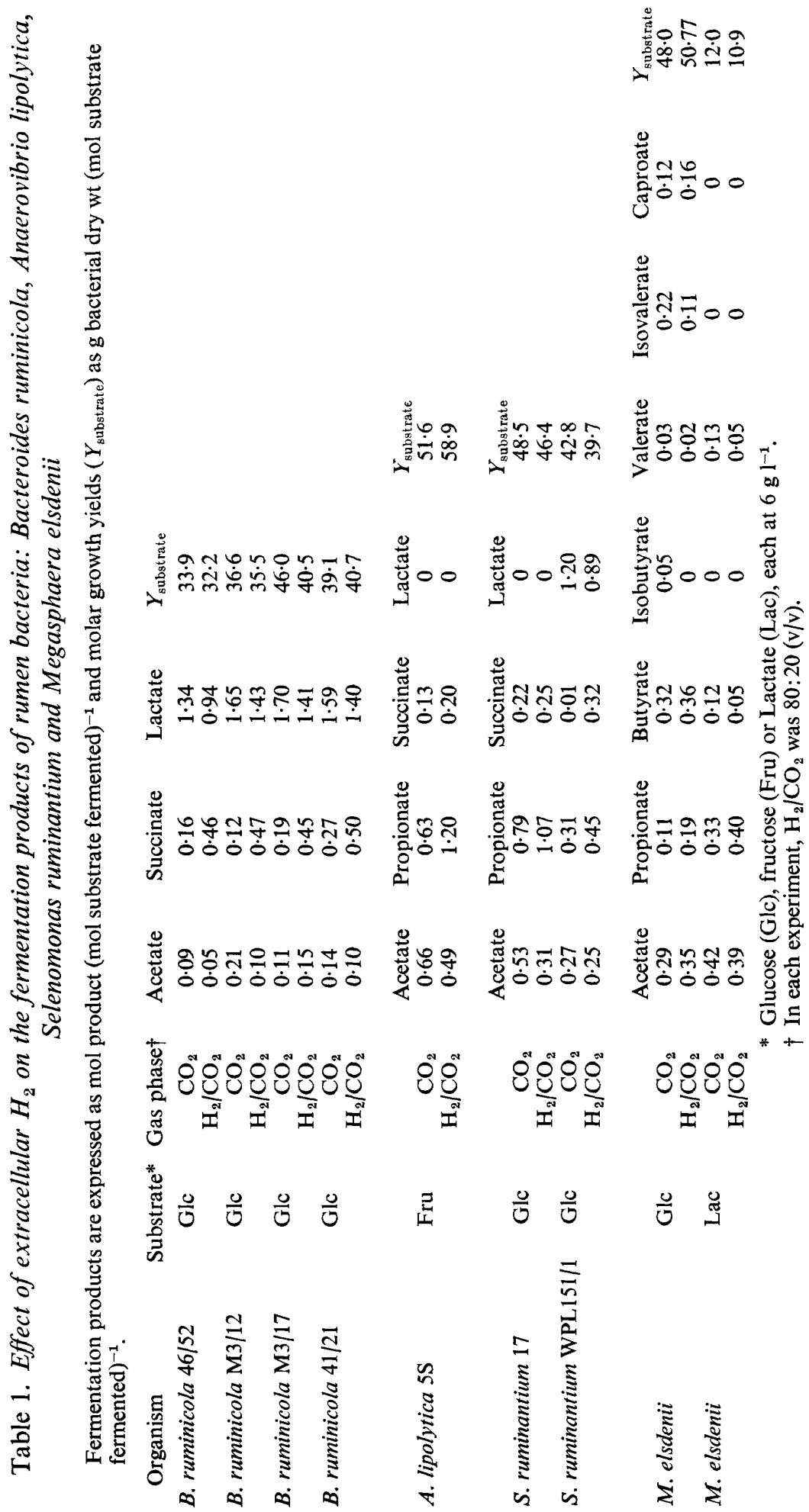


Table 2. Hydrogenase activity and substrate affinity in whole cells and cell fractions of Bacteroides ruminicola, Anaerovibrio lipolytica and Selenomonas ruminantium

\begin{tabular}{|c|c|c|c|c|}
\hline \multirow[b]{2}{*}{ Organism } & \multicolumn{2}{|c|}{$\begin{array}{c}\text { Activity } \\
{[\mu \mathrm{mol} \text { benzyl viologen reduced }} \\
\left.\min ^{-1}(\mathrm{~g} \text { bacterial dry } \mathrm{wt})^{-1}\right]\end{array}$} & \multicolumn{2}{|c|}{$\begin{array}{c}\text { Activity after high-speed } \\
\text { centrifugation } \\
{[\mu \mathrm{mol} \text { benzyl viologen reduced }} \\
\left.\min ^{-1}(\mathrm{~g} \text { protein })^{-1}\right]\end{array}$} \\
\hline & Whole cells & Broken cell suspension & Pellet & Supernatant \\
\hline B. ruminicola & $54\left(4.5 \times 10^{-6}\right)^{*}$ & $73\left(6.0 \times 10^{-6}\right)$ & 184 & 0 \\
\hline A. lipolytica & $40\left(1.4 \times 10^{-5}\right)$ & $45(\mathrm{ND})$ & 67 & 0 \\
\hline S. ruminantium & $105\left(4.4 \times 10^{-5}\right)$ & $130\left(4.8 \times 10^{-5}\right)$ & 227 & 0 \\
\hline
\end{tabular}

significant changes in growth yields with these changes in fermentation products was unexpected. Hobson \& Summers (1972) suggested that propionate production would yield more ATP than acetate production and it was also assumed that propionate and succinate production would yield more ATP than lactate production.

Megasphaera elsdenii showed small increases in the proportion of propionate under $\mathrm{H}_{2} / \mathrm{CO}_{2}$ atmospheres, but these were not large enough to require the net uptake of extracellular $\mathrm{H}_{2}$ and could have been achieved by use of $\mathrm{H}_{2}$ formed in association with acetate production. Similar results were obtained by Van Nevel et al. (1974) with M. elsdenii grown under $\mathrm{H}_{2}$ atmospheres.

The bacteria selected for further study were $B$. ruminicola strain $46 / 52$, A. lipolytica strain $5 \mathrm{~S}$ and $S$. ruminantium strain WPL151/1. Table 2 shows the hydrogenase activities associated with whole cells or cell fractions of these three bacteria. In each case there was some increase in the hydrogenase activity of cells following ultrasonic disruption. Also, in each case the activity was found entirely in the membrane pellet sedimented at $100000 \mathrm{~g}$. In each bacterium the hydrogenase had a relatively broad $\mathrm{pH}$ optimum between $\mathrm{pH} 7.0$ and 8.0; below $\mathrm{pH} 7.0$ the activity decreased rapidly. To determine the apparent $K_{\mathrm{m}}$ for $\mathrm{H}_{2}$, a phosphate buffer solution was saturated with $\mathrm{H}_{2}$ gas at $20^{\circ} \mathrm{C}$ and atmospheric pressure and then portions of this solution were added to the assay mixture in anaerobic cuvettes. The saturated $\mathrm{H}_{2}$ solution was calculated to contain $0.8 \mathrm{~mm}-\mathrm{H}_{2}$ (Handbook of Chemistry and Physics; CRC Press) which was very close to values determined by Erbes \& Burris (1978). Table 2 shows that values obtained for the apparent $K_{\mathrm{m}}$ for $\mathrm{H}_{2}$ did not vary significantly between whole bacteria and broken cell suspensions of the bacteria tested. In none of these bacteria could formate dehydrogenase activity be detected.

Hungate et al. (1970) reported a value of $1 \times 10^{-6} \mathrm{M}$ for the apparent $K_{\mathrm{m}}$ for $\mathrm{H}_{2}$ of the hydrogenase of the rumen bacterium Methanobacterium ruminantium. In $B$. ruminicola the $K_{\mathrm{m}}$ was four to six times higher than that of $M$. ruminantium, while those of $A$. lipolytica and $S$. ruminantium were, respectively, 10 and 40 times higher. It follows that in competition for $\mathrm{H}_{2}$ in the rumen, the methanogenic bacteria have an advantage over the propionate/ succinate-producers studied here. If, however, methanogenesis were selectively inhibited by chemical additives, the hydrogenases of the propionate/succinate-producers should be capable of maintaining a very low $\mathrm{H}_{2}$ tension, provided a sufficiency of electron acceptors were present.

As with the hydrogenase activities, the fumarate reductases of the three bacteria studied were associated with the membrane pellet (Table 3). Disruption of the cells resulted in two- to threefold increases in the activity of fumarate reductase. Addition of Triton X-100 $(2 \%, v / v)$ to the assays did not affect the fumarate reductase activity of the whole bacteria. 
Table 3. Fumarate reductase activity and substrate affinity in whole cells and cell fractions of Bacteroides ruminicola, Anaerovibrio lipolytica and Selenomonas ruminantium

\begin{tabular}{|c|c|c|c|c|}
\hline \multirow[b]{2}{*}{ Organism } & \multicolumn{2}{|c|}{$\begin{array}{c}\text { Activity } \\
\text { [ } \mu \mathrm{mol} \text { benzyl viologen oxidized } \\
\left.\min ^{-1}(\mathrm{~g} \text { bacterial dry } \mathrm{wt})^{-1}\right]\end{array}$} & \multicolumn{2}{|c|}{$\begin{array}{c}\text { Activity after high-speed } \\
\text { centrifugation } \\
{[\mu \mathrm{mol} \text { benzyl viologen oxidized }} \\
\left.\min ^{-1}(\mathrm{~g} \text { protein })^{-1}\right]\end{array}$} \\
\hline & Whole cells & Broken cell suspension & Pellet & Supernatant \\
\hline B. ruminicola & $423\left(1.5 \times 10^{-4}\right)^{*}$ & $800\left(0.9 \times 10^{-4}\right)$ & 1757 & 0 \\
\hline A. lipolytica & $817\left(1 \cdot 7 \times 10^{-4}\right)$ & $2600\left(1.7 \times 10^{-4}\right)$ & 2990 & 0 \\
\hline S. ruminantium & $347\left(1.8 \times 10^{-4}\right)$ & $1100\left(0.8 \times 10^{-4}\right)$ & 2377 & 0 \\
\hline
\end{tabular}

* Values in parentheses show apparent $K_{\mathrm{m}}$ for fumarate (M).
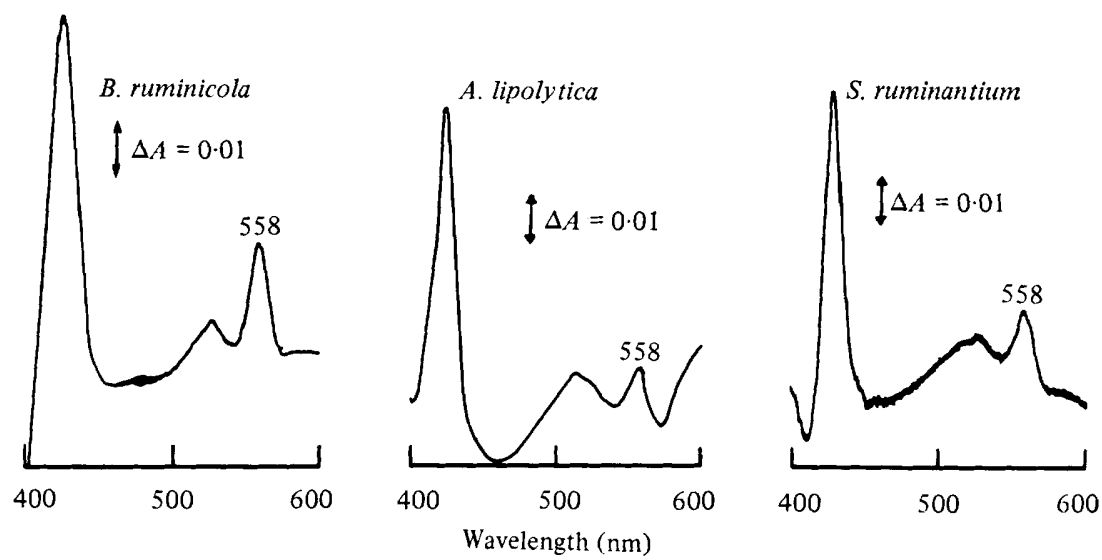

Fig. 1. Hydrogen-reduced minus air-oxidized difference spectra of ultrasonically disrupted Bacteroides ruminicola, Anaerovibrio lipolytica and Selenomonas ruminantium. Suspensions contained $10 \cdot 5,8 \cdot 1$ and $9 \cdot 7 \mathrm{mg}$ dry wt bacteria $\mathrm{ml}^{-1}$, respectively.

The values obtained for the apparent $K_{\mathrm{m}}$ for fumarate (Table 3) were lower than values normally expected for the concentration of intracellular intermediates of the Kreb's Cycle (Lowry et al., 1971). It is possible, however, that the anaerobic bacteria used here, having an incomplete Kreb's Cycle, could have difficulties in maintaining fumarate concentrations at this level.

There was very little difference between the $K_{\mathrm{m}}$ values for fumarate reductases measured using whole cells or broken cell suspensions. This contrasted with the fivefold decrease in $K_{\mathrm{m}}$ reported by Kröger (1977) for the fumarate reductase of Vibrio succinogenes following disruption of the bacteria. The increase in $V_{\max }$ for fumarate reductase in broken cell suspensions, however, supports the belief that in the bacteria studied here the transport of fumarate across intact membranes was limiting the reductase reaction.

Cytochrome $b$ was present in each of the three bacteria and was shown to be associated with the membrane pellet. The amounts of cytochrome $b$ were estimated to be $0 \cdot 13,0.24$ and $0 \cdot 10 \mu \mathrm{mol}$ (g bacterial dry $\mathrm{wt})^{-1}$ in B. ruminicola, A. lipolytica and $S$. ruminantium, respectively.

When $\mathrm{H}_{2}$ gas was bubbled into spectrophotometer cuvettes containing $2.5 \mathrm{ml}$ of broken cell suspensions of these bacteria the cytochrome $b$ was reduced to give the difference spectra shown in Fig. 1. The reduction obtained in each case was equal to that achieved by adding excess sodium dithionite. Reduction of cytochrome $b$ was also obtained by adding $2.5 \mathrm{~mm}-\mathrm{NADH}$ to broken cell suspensions but in each case the steady-state reduction 
Table 4. Reduction of cytochrome b by $\mathrm{H}_{2}$ and $\mathrm{NADH}$ and re-oxidation by fumarate, in Bacteroides ruminicola, Anaerovibrio lipolytica and Selenomonas ruminantium

The reduction of cytochrome $b$ in broken cell suspensions was determined (i) after adding excess $\mathrm{H}_{2}$, (ii) after adding excess NADH $(2.5 \mathrm{~mm})$ and (iii) after adding excess fumarate $(2.5 \mathrm{~mm})$ to a preparation which had been fully reduced by $\mathbf{H}_{2}$. In each case, the percentage reduction of cytochrome $b$ is expressed relative to the reduction caused by excess sodium dithionite.

Percentage reduction of cytochrome $b$

\begin{tabular}{lccc}
\multicolumn{1}{c}{ Organism } & $\mathrm{H}_{\mathbf{2}}$ & $\mathrm{NADH}$ & $\mathbf{H}_{2} /$ fumarate \\
B. ruminicola & 100 & 86 & 13 \\
A. lipolytica & 100 & 79 & 48 \\
S. ruminantium & 100 & 73 & 40
\end{tabular}

of cytochrome $b$ was less than $100 \%$ (Table 4). A substantial re-oxidation of the cytochrome $b$ was obtained when excess sodium fumarate was added to the $\mathrm{H}_{2}$-reduced cell suspensions (Table 4).

The differences in the extent to which cytochrome $b$ was reduced by $\mathrm{H}_{2}$ and NADH suggest that there may be an extra cytochrome $b$ component in the pathway for $\mathrm{H}_{2}$ oxidation. Enoch \& Lester (1975) found that the purified formate dehydrogenase of Escherichia coli contained a $b$-type cytochrome and Kröger \& Innerhofer (1976) suggested that a similar association existed in Vibrio succinogenes. Preliminary studies on $B$. ruminicola and $S$. ruminantium using 2-heptyl-4-hydroxyquinoline $N$-oxide as an electron transport inhibitor also indicate the possibility of two cytochromes $b$ in the chain linking $\mathrm{H}_{2}$ oxidation with fumarate reduction, but further studies are required to clarify this. It is possible that in the ruminant animal where methanogenesis has been decreased by a specific inhibitor, the propionate/succinate-producing bacteria may be able to use $\mathrm{H}_{2}$ diverted from methanogenesis and so prevent an excessive increase in $\mathrm{H}_{2}$ tension. Should $\mathrm{H}_{2}$ accumulate the acetate $/ \mathrm{H}_{2}$-producing bacteria (e.g. Ruminococcus albus) would ferment hexoses to acetate and ethanol with a loss of potential ATP production (Thauer et al., 1977). The consequent loss of bacterial production may be responsible for the reported inhibitory effect of high $\mathrm{H}_{2}$ concentrations on cellulolytic bacteria (Chung, 1976).

To ensure that the propionate/succinate-producing bacteria could utilize $\mathrm{H}_{2}$ to their full potential the animals diet would have to contain a proportion of easily fermented carbohydrate to provide substrates for the bacteria. The formation of propionate rather than methane as the major reduced end-product of rumen fermentation would have a beneficial effect on the utilization of dietary energy by the animal.

I should like to thank Miss Shona Neil for skilled technical assistance during this study.

\section{REFERENCES}

Chung, K.-T. (1976). Inhibitory effects of $\mathrm{H}_{2}$ on growth of Clostridium cellobioparum. Applied and Environmental Microbiology 31, 342-348.

Demeyer, D. I. \& VAN NeVel, C. J. (1975). Methanogenesis, an integrated part of carbohydrate fermentation and its control. In Digestion and Metabolism in the Ruminant, Proceedings of the 4th International Symposium on Ruminant Physiology, pp. 366-382. Edited by I. W. McDonald \& A. C. I. Warner. Armidale, N.S.W., Australia: University of New England Publishing Unit.

De Vries, W., Van Wijck-Kapteijn, W. M. C. \& OOSTERHUIS, S. K. H. (1974). The presence and function of cytochromes in Selenomonas ruminantium, Anaerovibrio lipolytica and Veillonella alcalescens. Journal of General Microbiology 81, 69-78.

De Vries, W., Aleem, M. I. H., Hemrika-Wagner, A. \& Stouthamer, A. H. (1977). The functioning of cytochrome $b$ in the electron transport to fumarate in Propionibacterium freudenreichii and Propionibacterium pentosaceum. Archives of Microbiology 112, 271-276.

ENoCH, H. G. \& Lester, R. L. (1975). The purification and properties of formate dehydrogenase and nitrate reductase from Escherichia coli. Journal of Biological Chemistry 250, 6693-6705. 
ERbes, D. L. \& Burris, R. H. (1978). The kinetics of methyl viologen oxidation and reduction by hydrogenase of Clostridium pasteurianum. Biochimica et biophysica acta 525, 45-54.

Fell, B. F., Kay, M., Whitelaw, F. G. \& Boyne, R. (1968). Observations on the development of ruminal lesions in calves fed on barley. Research in Veterinary Science 9, 458-466.

Henderson, C. (1971). A study of the lipase of Anaerovibrio lipolytica: a rumen bacterium. Journal of General Microbiology 65, 81-89.

Henderson, C. (1975). The isolation and characterization of strains of lipolytic bacteria from the ovine rumen. Journal of Applied Bacteriology 39, 101-109.

Hobson, P. N. (1965). Continuous culture of some anaerobic and facultative anaerobic rumen bacteria. Journal of General Microbiology 38, 167-180.

Hobson, P. N. \& MANN, S. O. (1961). The isolation of glycerol-fermenting and lipolytic bacteria from the rumen of the sheep. Journal of General Microbiology 25, 227-240.

Hobson, P. N. \& Summers, R. (1972). ATP pool and growth yield in Selenomonas ruminantium. Journal of General Microbiology 70, 351-360.

Hobson, P. N., MANN, S. O. \& Oxford, A. E. (1958). Some studies on the occurrence and properties of a large Gram-negative coccus from the rumen. Journal of General Microbiology 19, $462-472$.

Hungate, R. E. (1966). The Rumen and its Microbes. New York \& London: Academic Press.

Hungate, R. E., Smith, W., Bauchop, T., Yu, I. \& RabinowitZ, J. C. (1970). Formate as an intermediate in the bovine rumen fermentation. Journal of Bacteriology 102, 389-397.

Jarvis, B. D. W., Henderson, C. \& Asmundson, R. V. (1978). The role of carbonate in the metabolism of glucose by Butyrivibrio fibrisolvens. Journal of General Microbiology 105, 287-295.

KRöGER, A. (1977). Phosphorylative electron transport with fumarate and nitrate as terminal hydrogen acceptors. Symposia of the Society for General Microbiology 27, 61-93.

KRÖGER, A. \& INNERHOFER, A. (1976). The function of $b$ cytochromes in the electron transport from formate to fumarate of Vibrio succinogenes. European Journal of Biochemistry 69, 497-506.

Kurihara, Y., Eadie, J. M., Hobson, P. N. \& ManN, S. O. (1968). Relationship between bacteria and ciliate protozoa in the sheep rumen. Journal of General Microbiology 51, 267-288.

Lowry, O. H., Carter, J., Ward, J. B. \& Glaser, L. (1971). The effect of carbon and nitrogen sources on the level of metabolic intermediates in Escherichia coli. Journal of Biological Chemistry 246, 6511-6521.

Lysons, R. J., Alexander, T. J. L., Hobson, P. N., MANN, S. O. \& Stewart, C. S. (1971). Establishment of a limited rumen microflora in gnotobiotic lambs. Research in Veterinary Science 12, 486-487.

PIRT, S. J. (1965). The maintenance energy of bacteria in growing cultures. Proceedings of the Royal Society B163, 224-231.

RedDY, A. C. \& PeCK, H. D. (1978). Electron transport phosphorylation coupled to fumarate reduction by $\mathrm{H}_{2}$ and $\mathrm{Mg}^{2+}$-dependent adenosine triphosphatase activity in extracts of the rumen anaerobe Vibrio succinogenes. Journal of Bacteriology 134, 982-991.

Thauer, R. K., Jungerman, K. \& Decker, K. (1977). Energy conservation in chemotrophic anaerobic bacteria. Bacteriological Reviews 41, $100-180$

Van Nevel, C. J., Prins, R. A. \& Demeyer, D. I. (1974). On the inverse relationship between methane and propionate in the rumen. Zeitschrift für Tierphysiologie, Tierernährung und Futtermittolkunde 33, 121-125.

Wolin, M. J., Wolin, E. A. \& JACoBs, N. J. (1961). Cytochrome-producing anaerobic vibrio, Vibrio succinogenes sp. n. Journal of Bacteriology 81, 911-917. 